Erratum

\title{
Erratum: Prats-Llinàs, M.T., et al. Post-Harvest Regulated Deficit Irrigation in Chardonnay Did Not Reduce Yield but at Long-Term, It Could Affect Berry Composition. Agronomy 2019, 9, 328
}

\author{
Agronomy Editorial Office
}

MDPI, St. Alban-Anlage 66, 4052 Basel, Switzerland; agronomy@mdpi.com

The authors would like to make the following correction to the published paper [1]:

The second "Harvest" in the title has been deleted. The correct title should be "Post-Harvest Regulated Deficit Irrigation in Chardonnay Did Not Reduce Yield but at Long-Term, It Could Affect Berry Composition".

The authors and editorial office would like to apologize for any inconvenience caused to the readers by these changes.

\section{Reference}

1. Prats-Llinàs, M.T.; Bellvert, J.; Mata, M.; Marsal, J.; Girona, J. Post-Harvest Harvest Regulated Deficit Irrigation in Chardonnay Did Not Reduce Yield but at Long-Term, It Could Affect Berry Composition. Agronomy 2019, 9, 328. [CrossRef]

(C) 2019 by the author. Licensee MDPI, Basel, Switzerland. This article is an open access article distributed under the terms and conditions of the Creative Commons Attribution (CC BY) license (http://creativecommons.org/licenses/by/4.0/). 